\title{
EFEKTIVITAS LKPD BERBASIS BLENDED LEARNING BERBANTUAN MULTIMEDIA INTERAKTIF UNTUK MELATIH VISUAL SPASIAL PESERTA DIDIK
}

\author{
Gaferianto Hulu $^{1}$, Kusumawati Dwiningsih ${ }^{2}$ \\ ${ }^{1,2}$ Pendidikan Kimia, Universitas Negeri Surabaya \\ Kampus Ketintang, Jalan Ketintang, Gayungan, Surabaya, Jawa Timur \\ 2e-mail:kd.kimia@gmail.com

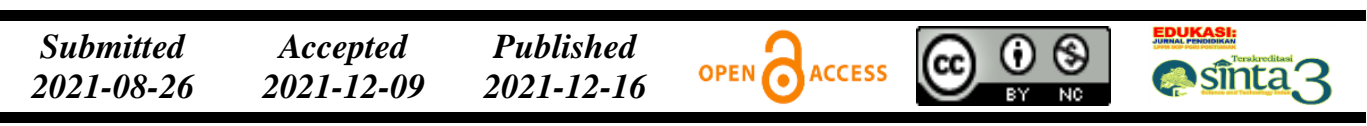

\begin{abstract}
Abstrak
Penelitian bertujuan untuk mengetahui keefektifan Lembar Kerja Peserta Didik (LKPD) berbasis blended learning berbantuan multimedia interaktif dalam melatih kemampuan visual spasial peserta didik pada materi Ikatan Kovalen. Metode penelitian menggunakan one group pretest-posttest design dengan melakukan uji coba terbatas pada peserta didik Jurusan Kimia Analisis SMK Negeri 1 Cerme Gresik yang dipilih berdasarkan kemampuan peserta didik dari kemampuan rendah, sedang, dan tinggi sebanyak 15 orang. Pretest dan posttest digunakan sebagai instrumen untuk mengetahui kemampuan visual spasial peserta didik. Data dianalisis secara deskriptif kuantitatif. Hasil penelitian menunjukkan bahwa data pretest dan posttest berdistribusi normal dan hasil rata-rata $N$-Gain pada kategori tinggi sehingga disimpulkan bahwa LKPD berbasis blended learning berbantuan multimedia interaktif dalam melatih kemampuan visual spasial peserta didik pada materi Ikatan Kovalen efektif sebagai bahan ajar.
\end{abstract}

Kata Kunci: ikatan kovalen; LKPD berbasis blended learning; visual spasial.

\begin{abstract}
The research aimed to determine the effectiveness of the Student Worksheet (LKPD) based on blended learning assisted by interactive multimedia in training students' visual-spatial skills in the Covalent Bond material. The research method used a one group pretest-posttest design by conducting a limited trial on students of the Analytical Chemistry Department at SMK Negeri 1 Cerme Gresik who were selected based on the ability of students from low, medium, and high abilities as many as 15 people. Pretest and posttest are used as instruments to determine the visual-spatial ability of students. Data were analyzed descriptively quantitatively. The results showed that the pretest and posttest data were normally distributed with the average $N$-Gain in the high category, so it can be concluded that the LKPD based on blended learning assisted by interactive multimedia in training students' visualspatial abilities on the Covalent Bond material is effective as teaching material.
\end{abstract}

Keywords: covalent bonding; LKPD-based blended learning; visual spatial.

\section{PENDAHULUAN}

Ikatan kimia maupun materi-materi kimia pada umumnya, meliputi tiga tingkatan berpikir dalam proses pembelajarannya, yaitu: level makroskopis yang merupakan hal-hal dapat diamati oleh indra, misalnya perubahan warna, bau, dan 
bentuk; level simbolik misalnya penulisan rumus kimia, rumus empiris, dan persamaan kimia; dan level submikroskopik yang tidak dapat diamati (Taber et al., 2012; Vrabec \& Prokša, 2016). Peserta didik dituntut memiliki kemampuan representasional yang baik ketika mempelajari konsep dasar seperti ikatan kimia. Ciri dari konsep tersebut memiliki tingkat representasi pada tingkat submikroskopis dan simbolik. Representasi pada tingkat dapat mewakili fenomena nyata dan mengubahnya menjadi tanda, simbol, dan grafik yang disebabkan oleh keterbatasan indra manusia untuk mengamati secara jelas atom, molekul, atau senyawa (Widarti et al., 2018; Pérez et al., 2017).

Submateri Ikatan Kimia, seperti ikatan kovalen, mengandung banyak jenis bentuk molekul yang membutuhkan visualisasi dalam proses pembelajaran. Kurangnya visualisasi dalam proses pembelajaran membuat sebagian peserta didik tidak dapat memahami dengan jelas ketika hanya membayangkannya saja. Hal tersebut berkorelasi dengan temuan mengenai masalah proses visualisasi terkait dengan visualisasi ikatan kovalen. Materi Ikatan Kovalen merupakan materi yang bersifat abstrak terutama pada proses pembentukan ikatan kovalen serta bentuk molekul (Noviani \& Istiyadji, 2017). Visualisasi materi yang bersifat abstrak, peserta didik akan memperoleh pemahaman yang tepat (Pérez et al., 2017).

Salah satu kecerdasan yang berhubungan dengan visualisasi yaitu visual spasial. Visual spasial merupakan kecerdasan gambar atau pandang ruang yang memiliki kemampuan mempersepsi dunia visual dan spasial terhadap kepekaan warna, keseimbangan, pola, mempresentasikan ide secara visual, dan spasial serta mengorientasi yang bertumpu pada ketelitian pengamatan (Yaumi, 2017). Kecerdasan visual spasial melibatkan penggunaan kemampuan mental untuk membayangkan gambaran imajiner. Tingkat pemahaman yang lebih tinggi, visual spasial ditandai dengan penggunaan logika dan memproses secara kreatif gambar imajiner untuk memecahkan masalah (Mccormack, 2017).

Kemampuan visual spasial diperlukan dalam materi kimia, misalnya kepolaran suatu molekul, transformasi bentuk molekul 2D menjadi 3D ataupun sebaliknya, dan identifikasi isomer geometri yang menuntut peserta didik secara 
Edukasi: Jurnal Pendidikan, Volume 19 Nomor 2 Tahun 2021

Efektivitas LKPD Berbasis Blended Learning Berbantuan Multimedia .......

Gaferianto Hulu, Kusumawati Dwiningsih

Halaman 319-333

mental (imajinatif) untuk merotasi ikatan-ikatan pada molekul. Proses membangun visualisasi secara mental pada materi Ikatan Kovalen membutuhkan kemampuan memahami rumus struktur kemudian membayangkan ke dalam representasi tiga dimensi (Jiang et al., 2016). Perlu adanya peningkatan kemampuan visual spasial diantaranya kemampuan merotasi, menentukan simetris dari molekul kimia, dan mentransformasi bentuk molekul 2D menjadi 3D ataupun sebaliknya (Achuthan et al., 2018).

Berdasarkan hasil wawancara terhadap guru Kimia SMK Negeri 1 Cerme Gresik, selama proses pembelajaran di kelas, metode yang digunakan hanya menggunakan metode presentasi, penggunaan media pembelajaran Fisika seperti molymod (model bentuk molekul) terbatas, dan media pembelajaran digital dibatasi sampai pengguna penyajian PowerPoint yang terdiri dari uraian materi yang tidak dapat mewakili fenomena submikroskopis dan simbolik, serta penyajian yang tidak jelas juga membuat peserta didik merasa tidak tertarik. Hal tersebut memengaruhi motivasi belajar peserta didik yang kurang ketika belajar kimia. Hal tersebut berkorelasi dengan temuan artikel hasil penelitian yang menunjukkan ikatan kovalen dan geometri molekul membutuhkan representasi partikel yang tidak teramati oleh peserta didik (tingkat submikroskopis) sehingga peserta didik sulit untuk memahaminya dan menguasai materi tersebut (Mufarohah \& Dwiningsih, 2018; Becker, et al., 2015; Chiang et al., 2014).

Karakteristik guru di era Revolusi Industri 4.0 seharusnya menerapkan metode pengajaran yang menempatkan peserta didik sebagai pembelajar aktif dan menempatkan diri sebagai salah satu sumber belajar. Kreativitas guru dalam memilih dan menggunakan model/media pembelajaran yang relevan serta memotivasi peserta didik dalam mempelajari mata pelajaran Kimia. Proses pembelajaran era milenial semakin efektif, efesien, interaktif, luas, dan tidak terpola hanya dalam ruang kelas (Nasution, 2016). Proses pembelajaran blended learning adalah penggunaan solusi pelatihan efektif dan efisien yang ditetapkan secara terkoordinasi untuk mencapai tujuan pembelajaran (Sakillah, 2020; Muhson, 2019; Zainuddin \& Keumala, 2018; Bibi, 2015; Pratiwi et al., 2013). 
Pembelajaran menggunakan blended learning membantu dan memungkinkan peserta didik untuk mencapai kompetensi yang menjadi tuntutan abad ke-21 (twenty-first comptencies) (Hogan, 2011; Mufarohah \& Dwiningsih, 2018). Berdasarkan hasil angket prapenelitian, $78,9 \%$ peserta didik menyatakan bahwa LKPD yang pernah digunakan hanya memuat soal atau percobaan tanpa adanya fenomena pemecahan masalah dalam LKPD. Sebanyak 93,93\% peserta didik menyatakan bahwa guru belum menggunakan proses pembelajaran online untuk memudahkan peserta didik dalam memperoleh informasi melalui perkembangan teknologi. Diperlukan bahan ajar yang bisa melatihkan visual spasial peserta didik dalam mengatasi kesulitan peserta didik tersebut, yaitu LKPD berbasis blended learning berbantuan multimedia interaktif pada materi Ikatan Kovalen.

\section{METODE}

Penelitian dilakukan menggunakan desain penelitian one group pretestpostest dengan melakukan uji coba terbatas pada peserta didik Jurusan Kimia Analisis SMK Negeri 1 Cerme Gresik yang dipilih berdasarkan kemampuan peserta didik dari kemampuan rendah, sedang, dan tinggi sebanyak 15 orang untuk mengetahui keefektifan LKPD. Pretest digunakan untuk mengukur kemampuan hasil belajar dan kemampuan visual spasial awal yang telah menggunakan sistem pembelajaran lama yang telah diterapkan di sekolah. Posttest digunakan untuk mengukur hasil belajar dan kemampuan visual spasial setelah menggunakan sistem pembelajaran baru atau LKPD yang dikembangkan dengan $\mathrm{X}$ adalah sistem kerja baru/treatment (Sugiyono, 2017) seperti yang terlihat di Gambar 1.

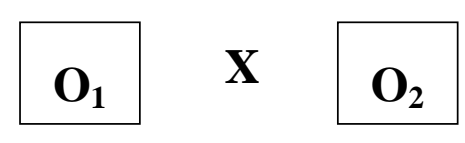

\section{Gambar 1 Model One Group Pretest-Posttest Design}

Pengumpulan data menggunakan tes pilihan ganda. Data hasil pretest dan posttest diuji dengan uji normalitas untuk mengetahui data berdistriubis normal atau tidak. Data kemudian diuji dengan SPSS dan harus mendapatkan nilai signifikasi lebih dari $0,05(\alpha>0,05)$, yang artinya jika hasil nilai siginifikansi 
(Sig.) lebih besar dari 0,05, maka data uji coba terbatas yang telah didapatkan berdistribusi normal.

Hasil data pretest dan posttest akan diproses dengan gain score yang dinormalisasi (N-Gain). Rumus $N$-Gain menggunakan rumus (1).

$$
G=\frac{\text { Skor postest-skor pretest }}{\text { skor maksimal (100)-skor pretest }} \times 100
$$

Pengolahan hasil $\mathrm{N}$-Gain diinterpretasikan dalam kategori yang ditunjukkan di Tabel 1. Intepretasi digunakan sebagai tolok ukur efektivitas multimedia yang digunakan peserta didik.

Tabel 1 Klasifikasi Nilai $N$-Gain

\begin{tabular}{cc}
\hline Nilai & Kriteria \\
\hline$G \geq 0,7$ & Tinggi \\
$0,3 \leq G<0,7$ & Sedang \\
$\mathrm{G}<0,3$ & Rendah \\
\hline
\end{tabular}

Berdasarkan kriteria skor N-Gain, LKPD berbasis blended learning dikatakan efektif apabila dari rata-rata skor gain kecerdasan visual spasial peserta didik yang diperoleh lebih dari atau sama dengan $0,3(\mathrm{G} \geq 0,3)$ atau mencapai kriteria "sedang" atau "tinggi".

\section{HASIL DAN PEMBAHASAN}

\section{Hasil Uji Normalitas}

Hasil uji normalisasi yang menggunakan Kolmogorov-Smirnov dapat dilihat di Tabel 2.

Tabel 2 Hasil Uji Normalitas Kolmogorov-Smirnov

\begin{tabular}{ccc}
\hline \multicolumn{3}{c}{ One-Sample Kolmogorov-Smirnov Test } \\
\hline \multicolumn{3}{c}{$\begin{array}{c}\text { Unstandardized } \\
\text { Predicted Value }\end{array}$} \\
\hline$N$ & 15 & \\
Normal Parameters & Mean & 85,3333333 \\
Most Extreme & Std. Deviation & 2,27921153 \\
Differences & Absolute & 0,167 \\
& Positive & 0,167 \\
& Negative & $-0,167$ \\
\hline \multicolumn{2}{c}{ Test Statistic } & 0,167 \\
\hline \multicolumn{2}{c}{ Asymp. Sig. (2-tailed) } & 0,200
\end{tabular}


Berdasarkan Tabel 2, terlihat bahwa tingkat signifikansi dua kriteria (pretest dan posttest kecerdasan visual-spasial) memiliki taraf signifikansi $(\alpha) 0,167$, sehingga disimpulkan bahwa hasil data pretest dan posttest berdistribusi normal.

\section{Efektivitas LPKD Berdasarkan N-Gain}

Hasil pretest dan posttest kemampuan visual spasial terlihat di Tabel 3.

Tabel 3 Hasil Pretest dan Posttest Visual Spasial

\begin{tabular}{ccccc}
\hline Kode Siswa & Pretest & Postest & $\boldsymbol{N}$-Gain & Kategori \\
\hline A & 30 & 80 & 0,71 & Tinggi \\
B & 30 & 70 & 0,57 & Sedang \\
C & 50 & 90 & 0,8 & Tinggi \\
D & 40 & 90 & 0,83 & Tinggi \\
E & 30 & 90 & 0,85 & Tinggi \\
F & 20 & 90 & 0,87 & Tinggi \\
G & 50 & 90 & 0,8 & Tinggi \\
H & 40 & 90 & 0,83 & Tinggi \\
I & 40 & 80 & 0,66 & Sedang \\
J & 20 & 90 & 0,87 & Tinggi \\
K & 10 & 80 & 0,77 & Tinggi \\
L & 30 & 90 & 0,85 & Tinggi \\
M & 10 & 80 & 0,77 & Tinggi \\
N & 20 & 80 & 0,75 & Tinggi \\
O & 30 & 90 & 0,85 & Tinggi \\
\hline
\end{tabular}

Berdasarkan Tabel 3, terlihat bahwa pretest dan posttest kecerdasan visual spasial memiliki skor $\mathrm{N}$-Gain dengan kategori rentang dari sedang-tinggi. Hal tersebut berarti pemanfaatan multimedia interaktif 3D pada pembelajaran Ikatan Kovalen berpengaruh terhadap kecerdasan visual spasial peserta didik. Penggunaan LKPD berbasis blended learning berbantuan multimedia interaktif merupakan jalan yang tepat untuk memahami konsep Ikatan Kovalen. Pemanfaatan LKPD dapat membuat pengalaman belajar yang bermakna sehingga mudah diserap oleh peserta didik pada pembelajaran geometri molekul (Tasker, 2014). Dampak penggunaan LKPD yang tepat akan memberikan jalan alternatif kepada peserta didik dalam upaya memahami konsep secara mandiri dan memperkuat keterampilan representasionalnya (Tasker, 2014). Pemanfaatan LKPD dalam proses pembelajaran secara interaktif menimbulkan efek latensi sehingga kemungkinan untuk memperoleh konsep semakin kuat disertai dengan 
Edukasi: Jurnal Pendidikan, Volume 19 Nomor 2 Tahun 2021

Efektivitas LKPD Berbasis Blended Learning Berbantuan Multimedia .......

Gaferianto Hulu, Kusumawati Dwiningsih

Halaman 319-333

peningkatan kecerdasan visual spasial (Fernandes \& Yamanaka, 2019).

Tabel 3 juga menunjukkan bahwa peserta didik mengalami peningkatan kecerdasan visual spasial yang ditunjukkan pada hasil $N$-Gain dengan 13 orang peserta didik masuk kategori tinggi dan 2 orang peserta didik masuk kategori sedang. Selama proses pembelajaran online maupun offline peserta didik belajar secara mandiri dalam menemukan konsep Ikatan Kovalen. Pembelajaran dilakukan dengan berpusat pada peserta didik dengan guru hanya sebagai fasilitator. Pembelajaran dengan pendekatan student-centered learning akan meningkatkan hasil belajar peserta didik (Marlianto, 2021; Lesmana \& Arpan, 2017; Eviliyanto \& Nurekawati, 2017; Yulianingsih \& Hadisaputro, 2013). Peserta didik dibimbing dan diarahkan supaya bisa mengikuti kegiatan pembelajaran. LKPD dibuat untuk mengarahkan kegiatan pembelajaran baik secara online maupun offline. Kegiatan-kegiatan pada LKPD disusun untuk melatihkan visual spasial peserta didik dengan mengorientasi, menyelidiki, mengaplikasi, sampai peserta didik menemukan konsep Ikatan Kovalen.

Langkah awal pembelajaran yang dilakukan secara online yaitu peserta didik mendaftar pada website e-chemedu.com untuk bergabung ke kelas maya yang telah dibuat. Guru dan peserta didik berinteraksi secara online untuk membahas materi yang disampaikan. E-learning akan mampu menunjang pembelajaran online jika memenuhi tiga syarat, yaitu sederhana, personal, dan cepat (Elyas, 2018). Media $e$ learning yang dimanfaatkan harus mampu memberi kemudahan pengaksesan kepada peserta didik, sehingga peserta didik akan merasa nyaman dalam belajar walaupun secara online.

Website e-chemedu.com yang digunakan memiliki fitur-fitur yang membantu peserta didik seperti fitur modul, chat, pengumpulan tugas, diskusi kelompok, dan video pembelajaran yang menunjang proses pembelajaran seperti yang ditunjukkan di Gambar 2. Gambar 2 menunjukkan tampilan awal website E-Chemedu yang memberikan fasilitas ke peserta didik agar dapat bergabung dalam kelas online yang mempelajari materi Ikatan Kovalen. 


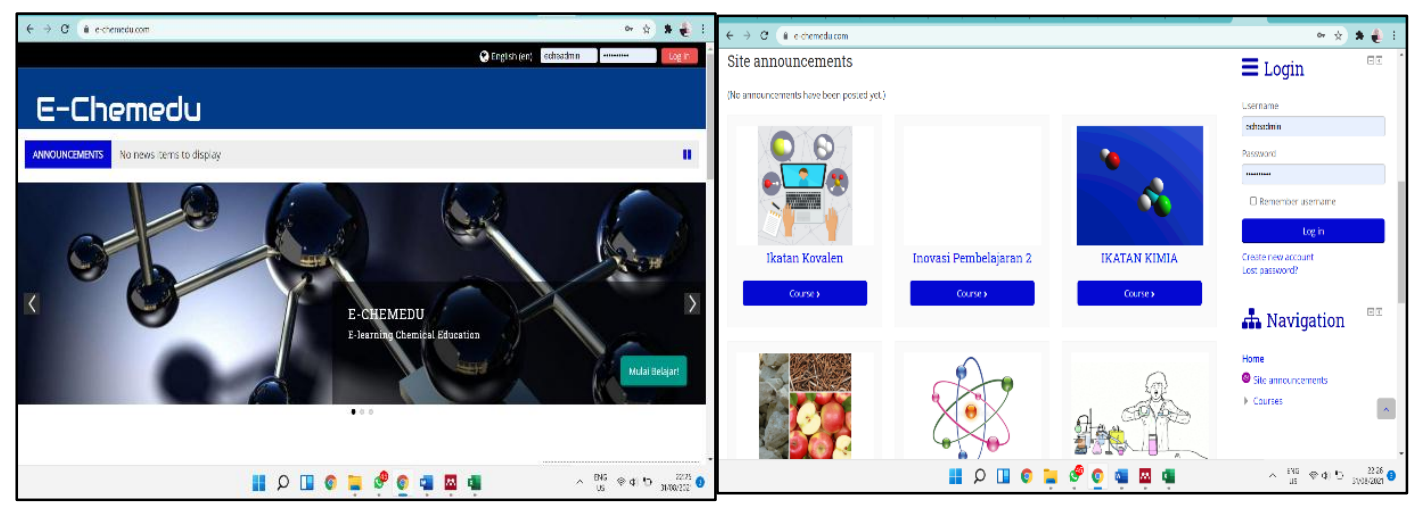

\section{Gambar 2 Tampilan Website E-Chemedu}

Selanjutnya setelah bergabung di kelas Ikatan Kimia, peserta didik akan mempelajari materi dengan LKPD berbantuan multimedia interaktif seperti yang terlihat di Gambar 3.

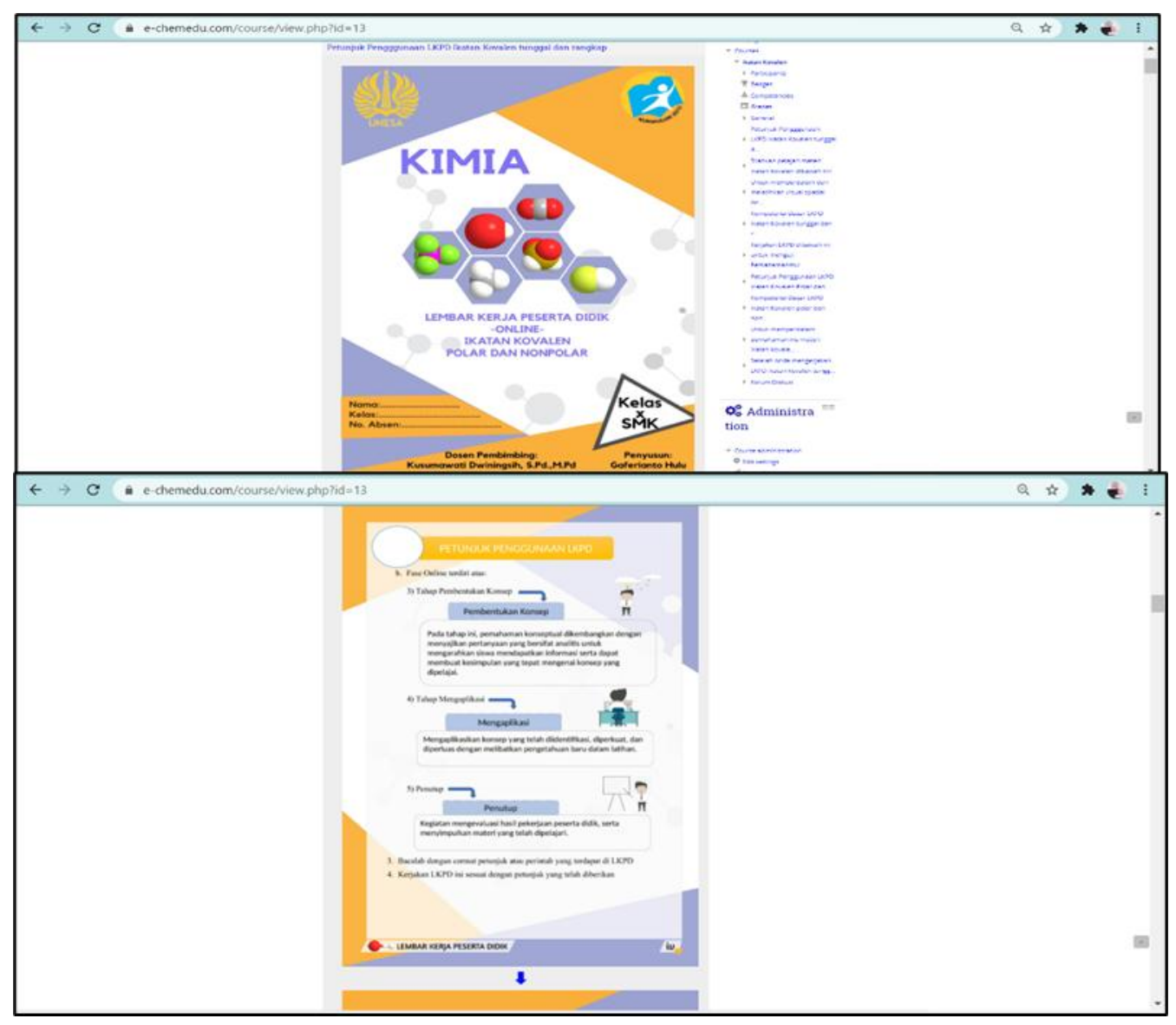

Gambar 3 Tampilan LKPD Berbasis Blended Learning

Permasalahan-permasalahan yang dihadapi peserta didik berdasarkan penelitian yang pernah dilakukan yaitu ketika guru menjelaskan, terdapat sikap 
yang kurang memperhatikan dan malu bertanya terhadap materi yang disampaikan (Rizqi et al., 2018). Media e-learning yang diberikan dapat membantu peserta didik memiliki interaksi antara guru dan peserta didik secara personal terhadap setiap masalah yang peserta didik dihadapi karena terdapat fitur forum diskusi yang tersedia pada website e-learning tersebut. Peserta didik dengan leluasa berdiskusi dengan peserta didik lain karena tidak dibatasi oleh waktu. Peserta didik mampu belajar secara mandiri maupun berkelompok yang ditunjukkan Gambar 4 . Hal tersebut merupakan kelebihan pembelajaran blended learning dimana proses belajar di kelas yang dibatasi oleh waktu dan dapat dilakukan di luar kelas secara online tanpa ada batasan waktu. Peserta didik lebih fleksibel, memiliki waktu yang efisien, dan membantu peserta didik fokus pada tugas yang dikerjakan (Sistek \& Chandler, 2019).

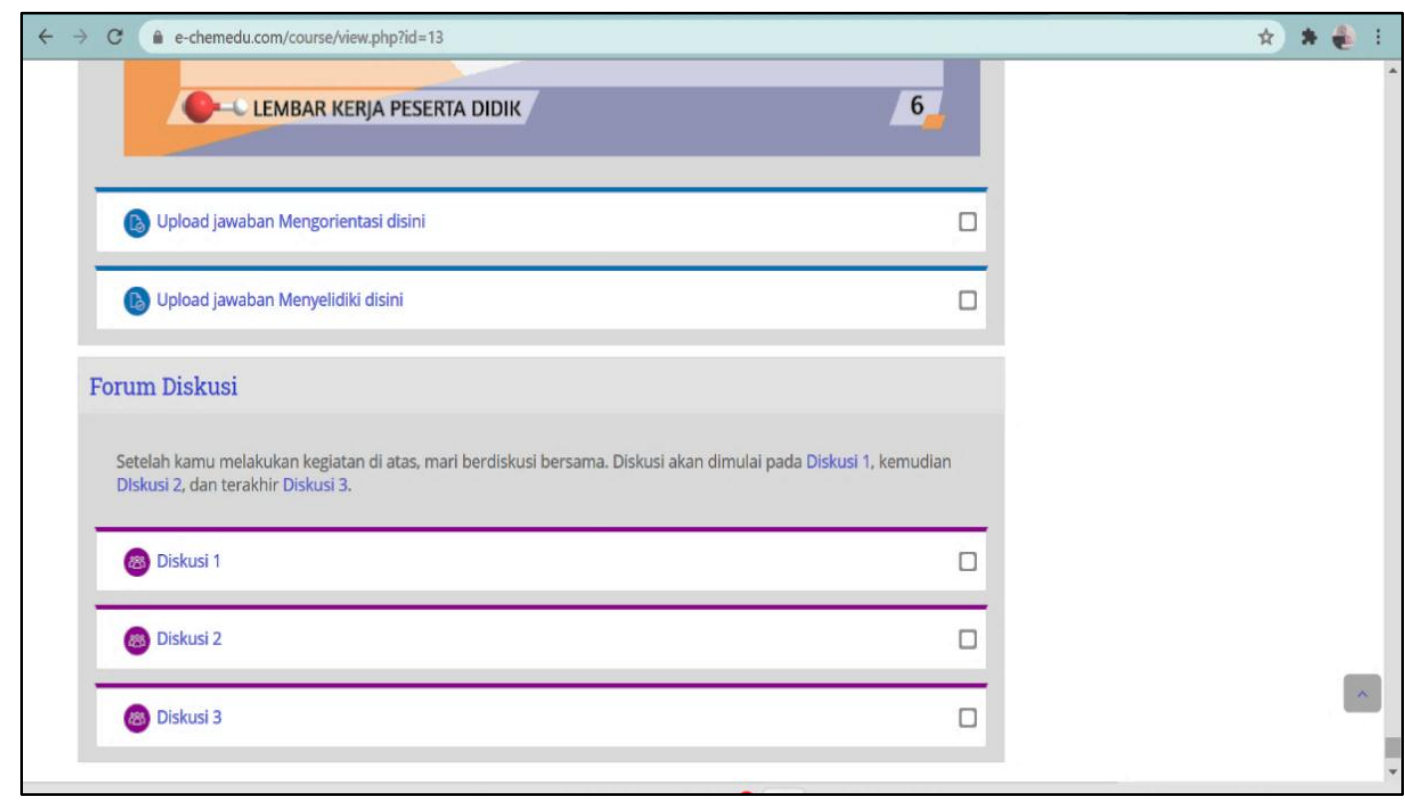

\section{Gambar 4 Forum Diskusi yang Terdapat dalam Website E-Chemedu}

Selain kelebihan, terdapat juga kekurangan dalam penerapan pembelajaran berbasis blended learning yaitu kurangnya paket data internet yang dimiliki oleh peserta didik, sehingga ketika mengakses website e-learning, masih banyak yang terlambat. Pengumpulan tugas dilaksanakan setelah dua hari pemberian tugas, sehingga peserta didik terbantu dan terfasilitasi. Pembelajaran secara tatap muka dilakukan dengan memanfaatkan Google Meet karena situasi pandemi COVID19. Setelah diberikan tugas LKPD secara online pada saat pertemuan dengan 
Google Meet, peserta didik bersama guru membahas LKPD yang telah dikerjakan. Penunjang proses pembelajaran bertujuan untuk membantu melatihkan visual spasial peserta didik pada submateri Ikatan Kovalen. LKPD untuk mengarahkan konsep kepada peserta didik, dimulai dengan fenomena dalam kehidupan seharihari. Berdasarkan hasil penelitian terdahulu, diketahui bahwa dengan mengaitkan fenomena kimia dalam kehidupan sehari-hari, maka pelajaran kimia akan terhindar dari kesan abstrak (Subagia, 2014).

Materi Ikatan Kovalen bersifat abstrak karena terdapat level submikroskopis seperti bentuk molekul, proses pembentukan ikatan yang perlu divisualisasikan dengan gambar 2D maupun 3D. Peserta didik sudah memahami bagaimana penulisan struktur Lewis dan mengetahui bagaimana proses pembentukan ikatan kovalen. Berdasarkan hasil posttest peserta didik pada indikator struktur Lewis pada proses pembentukan ikatan kovalen sebanyak 63,8\% menjawab benar. Hal tersebut disebabkan karena peserta didik kurang teliti mengamati gambar yang terdapat pada soal. Gambar tersebut bertujuan untuk menguji bagaimana hasil visual spasial peserta didik setelah diberikan LKPD. Visual spasial membantu peserta didik memahami sifat abstrak materi ikatan kovalen (Noviani \& Istiyadji, 2017). Visual spasial merupakan salah satu kecerdasan yang berhubungan dengan gambar atau pengamatan. Melatihkan visual spasial kepada peserta didik dapat meningkatkan hasil belajar karena terdapat pengaruh signifikan pada interaksi antara strategi pembelajaran dan gaya kognitif peserta didik (Rosari, 2019).

Struktur kognitif peserta didik akan meningkat seiring bertambahnya usia, dari refleks awal hingga aktivitas mental yang kompleks (Nursalim et al., 2017). Peserta didik akan membangun struktur pengetahuannya berdasarkan kematangan kognitif yang dimilikinya. Peserta didik di SMK Negeri 1 Cerme Gresik rata-rata berusia 15 tahun, pada tahap dan usia tersebut, menurut Piaget mampu berpikir secara abstrak, bernalar secara logis, dan sistematis dalam menyelesaikan masalah (Nursalim et al., 2017). LKPD dalam melatihkan visual spasial peserta didik mampu menyelesaikan soal-soal dengan kemampuan spasial yang dimiliki.

Hasil posttest yang telah diberikan pada indikator membedakan ikatan kovalen polar dan nonpolar dengan mempresentasikan gambar bentuk molekul 
menunjukkan bahwa sebanyak $80 \%$ peserta didik mampu menjawab soal dengan benar. Hal tersebut menunjukkan bahwa melalui LKPD berbantuan multimedia interaktif mampu melatihkan visual spasial peserta didik. Hal tersebut sejalan dengan hasil penelitian yang pernah dilakukan bahwa dengan bantuan multimedia dalam melatih visual spasial adanya peningkatan hasil jawaban benar dari peserta didik (Tamami \& Dwiningsih, 2020). Rata-rata gain score ternormaliasi dari data pretest dan posttest adalah 0,79 dengan kategori tinggi sehingga dapat disimpulkan bahwa LKPD berbassis blended learning berbantuan multimedia interaktif pada materi Ikatan Kovalen dinyatakan efektif sebagai bahan ajar yang dapat meningkatkan kemampuan visual spasial peserta didik.

\section{SIMPULAN}

Berdasarkan hasil penelitian, disimpulkan bahwa data pretest dan posttest berdistribusi normal dan rata-rata $N$-Gain masuk kategori tinggi sehingga LKPD berbasis blended learning berbantuan multimedia interaktif efektif dalam melatih kemampuan visual spasial peserta didik pada materi Ikatan Kovalen efektif sebagai bahan ajar.

\section{DAFTAR PUSTAKA}

Achuthan, K., Kolil, V. K., \& Diwakar, S. (2018). Using Virtual Laboratories in Chemistry Classrooms as Interactive Tools towards Modifying Alternate Conceptions in Molecular Symmetry. Education and Information Technologies, 23(6), 2499-2515. https://doi.org/10.1007/s10639-018-97271.

Becker, N., Stanford, C., Kota, M., \& Cole, R. (2015). Across Macroscopic, Submicroscopic, and Symbolic Levels: The Role of Instructor Facilitation in An Inquiry-Oriented Physical Chemistry Class. Chemistry Education

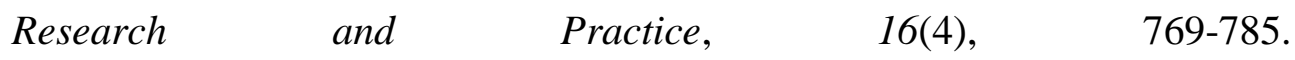
https://doi.org/10.1039/c5rp00064e\%0A.

Bibi, S. (2015). Efektivitas Penerapan Blended Learning terhadap Tingkat Pemahaman Mahasiswa Mata Kuliah Algoritma dan Pemrograman. Jurnal 
Pendidikan Informatika dan Sains, 4(2), 274-286.

http://dx.doi.org/10.31571/saintek.v4i2.76.

Chiang, C.-1., Xu, C., Han, Z., \& Ho, W. (2014). Real-Space Imaging of Molecular Structure and Chemical Bonding by Single-Molecule Inelastic Tunneling Probe. $\quad$ Science, 344(6186), 885-888. https://doi.org/10.1126/science.1253405.

Elyas, A. H. (2018). Penggunaan Model Pembelajaran E-Learning dalam Meningkatkan Kualitas Pembelajaran. Jurnal Warta, 56(04), 1-11. https://doi.org/10.46576/wdw.v0i56.4.

Eviliyanto, E., \& Nurekawati, E. (2017). Penerapan Model Problem Based Learning terhadap Hasil Belajar Mahasiswa Semester 5 Program Studi Pendidikan Geografi. Edukasi: Jurnal Pendidikan, 14(2), 212-222. http://dx.doi.org/10.31571/edukasi.v14i2.355.

Fernandes, R., \& Yamanaka, T. (2019). Interactive Design vs. Design for Interaction: Developing Interactive Play Tools that Promote Interactions between Children. IntechOpen. https://doi.org/10.5772/intechopen.84328.

Hogan, R. (2011). Blended Learning Examples in Education and Chemistry. Fiji: University of the South Pacific. https://doi.org/10.4018/978-1-60960-479$0 . \operatorname{ch} 005$.

Jiang, J., Zhao, Y., \& Yaghi, O. M. (2016). Covalent Chemistry beyond Molecules. Journal of the American Chemical Society, 138(10), 3255-3265. https://doi.org/10.1021/jacs.5b10666.

Lesmana, C., \& Arpan, M. (2017). Penerapan Model Pembelajaran Project Based Learning terhadap Kemampuan Psikomotor, Aktivitas Belajar, dan Respon Mahasiswa. Jurnal Pendidikan Informatika dan Sains, 6(1), 8-19. http://dx.doi.org/10.31571/saintek.v6i1.483.

Marlianto, F. (2021). Pengaruh Pembelajaran Kooperatif Tipe Team Assisted Individualization terhadap Hasil Belajar Materi Manajemen File. JUWARA: Jurnal Wawasan dan Aksara, 1(1), 58-68.

Mccormack A.J. (2017) Developing Visual/Spatial Thinking in Science Education. 
In: Taber K.S., Akpan B. (eds) Science Education. New Directions in Mathematics and Science Education. Rotterdam: SensePublishers. https://doi.org/10.1007/978-94-6300-749-8_11.

Mufarohah, S. L., \& Dwiningsih, K. (2018). Efektivitas LKS Berorientasi Blended Learning dengan Strategi Pogil pada Materi Ikatan Kimia SMA. JKPK (Jurnal Kimia dan Pendidikan Kimia), 3(2), 53-62. https://doi.org/10.20961/jkpk.v3i2.22328.

Muhson, N. (2019). Penerapan Blended Learning dalam Meningkatkan Hasil Belajar PAI Materi Sejarah Bani Umaiyah Kelas VIII SMPN 3 Pontianak. SOSIAL HORIZON: Jurnal Pendidikan Sosial, 6(1), 12-25. http://dx.doi.org/10.31571/sosial.v6i1.1230.

Nasution, T. (2016). Penerapan Metode Web Based Learning sebagai Solusi Pendidikan yang Efektif dan Efisien. Jurnal TIMES, 4(2), 49-52.

Noviani, M. W., Istiyadji, M., \& Kusasi, M. (2017). Miskonsepsi Ditinjau dari Penguasaan Pengetahuan Prasyarat untuk Materi Ikatan Kimia pada Kelas X. Jurnal Inovasi Pendidikan Sains, 8(1), 66-77.

Nursalim, M., Laksmiwati, H., Syafiq, M., Budiani, M. S., Savira, S. I., Khairunisa, R. N., \& Satwika, Y. W. (2017). Psikologi Pendidikan. Surabaya: Unesa University Press.

Pérez, J. R. B., Pérez, M. E. B., Calatayud, M. L., \& Sabater, J. V. (2017). Student's Misconceptions on Chemical Bonding: A Comparative Study between High School and First Year University Students. Asian Journal of Education and E-Learning, 05(01), 1-15.

Pratiwi, Sugiharto, \& Mulyani, B. (2013). Efektivitas Model Blended E-Learning Cooperative Approach Tipe TGT Dilengkapi Modul terhadap Prestasi Belajar Kimia Materi Pokok Hidrokarbon Kelas X Semester II SMA Negeri 5 Surakarta Tahun Ajaran 2011/2012. Jurnal Pendidikan Kimia (JPK), 2(1), 92-101.

Rizqi, A. A., Yusmansyah, \& Mayasari, S. (2018). Faktor-Faktor yang Mempengaruhi Motivasi Belajar. Jurnal FKIP Universitas, 6(2), 1-14.

Rosari, I. (2019). Pengaruh Strategi Pembelajaran dan Gaya Kognitif Spasial 
terhadap Hasil Belajar Ikatan Kimia SMA. IJIS Edu : Indonesian Journal of Integrated Science Education, 1(2), 163-168.

Sakillah, K., Hemafitria, H., \& Rianto, H. (2020). Pengaruh Penggunaan Model Blended Learning terhadap Hasil Belajar Siswa Kelas X TKR SMK Putra Khatulistiwa Pontianak. Jurnal Pendidikan Kewarganegaraan, 4(2), 116127. http://dx.doi.org/10.31571/pkn.v4i2.2108.

Sistek, C. M., \& Chandler. (2019). Exploring Online Learning Through Synchronous and Asynchronous Instructional Methods. USA: National University. https://doi.org/10.4018/978-1-7998-1622-5.

Subagia, I. W. (2014). Paradigma Baru Pembelajaran Kimia SMA. Prosiding Seminar Nasional MIPA UNDIKSHA.

Sugiyono. (2017). Metode Penelitian Kuantitatif, Kualitatif dan R\&D. Bandung: Alfabeta.

Taber, K. S., Tsaparlis, G., \& Nakiboğlu, C. (2012). Student Conceptions of Ionic Bonding: Patterns of Thinking Across Three European Contexts. International Journal of Science Education, 34(18), 2843-2873. https://doi.org/10.1080/09500693.2012.656150.

Tamami, A. A., \& Dwiningsih, K. (2020). The Effectivity of 3D Interactive Multimedia to Increase the Students' Visuospatial Abilities in Molecular. Jurnal Pendidikan dan Pengajaran, 53(3), 307-317. http://dx.doi.org/10.23887/jpp.v53i3.25883.

Tasker, R. (2014). Visualizing the Molecular World for a Deep Understanding of Chemistry. Teaching Science, 60(2), 15-27.

Vrabec, M., \& Prokša, M. (2016). Identifying Misconceptions Related to Chemical Bonding Concepts in the Slovak School System Using the Bonding Representations Inventory as a Diagnostic Tool. Journal of Chemical Education, 93(8), 1364-1370. https://doi.org/10.1021/acs.jchemed.5b00953.

Widarti, H. R., Safitri, A. F., \& Sukarianingsih, D. (2018). Identifikasi Pemahaman Konsep Ikatan Kimia. J-PEK (Jurnal Pembelajaran Kimia), 3(1), 41-50. https://doi.org/10.17977/um026v3i12018p041. 
Edukasi: Jurnal Pendidikan, Volume 19 Nomor 2 Tahun 2021

Efektivitas LKPD Berbasis Blended Learning Berbantuan Multimedia .......

Gaferianto Hulu, Kusumawati Dwiningsih

Halaman 319-333

Yaumi, M. (2017). Prinsip-Prinsip Desain Pembelajaran Disesuaikan dengan Kurikulum 2013. Jakarta: Kencana.

Yulianingsih, U., \& Hadisaputro, S. (2013). Efektivitas Pendekatan Student Centered Learning dengan Inkuiri Terbimbing untuk Meningkatkan Hasil Belajar. Chemistry in Education, 2(2), 149-155.

Zainuddin, Z., \& Keumala, C. M. (2018). Blended Learning Method within Indonesian Higher Education Institutions. Jurnal Pendidikan Humaniora, $6(2), 69-77$. 